\title{
Ethical issues involving long-term land leases: a soil sciences perspective
}

Cristian Timmermann ${ }^{1}$ and Georges F. Félix ${ }^{2}$

${ }^{1}$ Centro Interdisciplinario de Estudios en Bioética, Universidad de Chile, Chile, cristian.timmermann@gmail.com

${ }^{2}$ Farming Systems Ecology, Wageningen University and Research, The Netherlands

Preprint version of a published book chapter. Please refer to the final version and cite as:

Timmermann, Cristian and Georges F. Félix (2019), Ethical issues involving long-term land leases: a soil sciences perspective. In Sustainable governance and management of food systems: ethical perspectives, edited by Eija Vinnari and Markus Vinnari, 287-292. Wageningen: Wageningen Academic Publishers.

https://doi.org/10.3920/978-90-8686-892-6 


\title{
Ethical issues involving long-term land leases: a soil sciences perspective
}

\author{
Cristian Timmermann ${ }^{1}$ and Georges F. Félix ${ }^{2}$ \\ ${ }^{1}$ Centro Interdisciplinario de Estudios en Bioética, Universidad de Chile, Chile, \\ cristian.timmermann@gmail.com \\ ${ }^{2}$ Farming Systems Ecology, Wageningen University and Research, The Netherlands
}

Abstract: As populations grow and arable land becomes increasingly scarce, large-scale longterm land leases are signed at a growing rate. Countries and investors with large amounts of financial resources and a strong agricultural industry seek long-term land leases for agricultural exploitation or investment purposes. Leaders of financially poorer countries often advertise such deals as a fast way to attract foreign capital. Much has been said about the short-term social costs these types of leases involve, however, less has been said about the normative dimension of their long-term environmental impact. We therefore will focus on the likely impact such deals have for soil conservation, by (1) briefly introducing the basics of long-term leasing arrangements by comparing land leases to the renting of buildings, (2) explaining from a soil sciences perspective the difficulties in assessing the current value of an estate and in calculating the damages of soil erosion and degradation, and (3) show how difficult it is to incentivize the conservation of soil quality when one cannot sufficiently and cost-effectively valorize existing environmental capital and eventual future damages.

Attempting to oblige tenants through contracts to invest in sustainable stewardship has limited potential when liability payments do not reflect true costs and are hard to enforce.

Keywords: farm management, erosion, sustainable stewardship, conservation duties

\section{Introduction}

Arable land is becoming an increasingly scarce resource, as populations grow, desertification expands and poor land management continues to be the norm, soil erosion and degradation seem unavoidable (IPBES, 2018). Scarcity and uncertainty about the future has invited corporations, investors and states to acquire large amounts of fertile lands in foreign countries with vast amounts of land and poor economies, as a future investment or for current agricultural needs (De Schutter, 2011). Long-term land leases can at first sight appear as less controversial than the outright sale of such lands. Based on an interdisciplinary discussion between the authors, from applied philosophy and soil sciences, and a literature review, we show that these leases also involve substantial ethical issues, particularly regarding global justice, since soil conservation will have to mostly rely on the (corporate) social responsibility of land acquirers to secure future local food production capacities, as any contractual obligation will be hard to enforce.

Land leases are often perceived by governments of host countries as a fast way to attract foreign capital, providing jobs and allowing to invest in infrastructure. The terms of such agreements vary, ranging from years to decades, and they often involve areas of several thousand hectares. There are usually substantial power asymmetries between lenders and leasers, in favour of the latter, who are usually able to exert a substantial amount of pressure, backed by economic, political and sometimes even military power. Such deals have been criticized intensively in the past for the social injustices they lead to, particularly involving the forced relocation of indigenous communities and smallholders who lack formal property titles or are unable to defend their rights (Schiffman, 2013). In this chapter, we contribute to the discussion by drawing attention to another problem such deals involve and which is 
largely absent in the debate: the difficulty of incentivizing soil conservation in long-term land leases.

One of the main problems in incentivizing good land stewardship is that, in a world dominated by financial incentives, we cannot monetarize the true value of soils, a resource about which we still have only rudimentary knowledge and which we only now are beginning to take serious, as the urgency of highly publicized campaigns such as the United Nations International Year of the Soil in 2015 show (Ota et al., 2018). Currently land is given away at prices that are well below their regeneration costs, even in cases where regeneration is hardly possible or only achievable in the far future. Moreover, development indicators encourage countries to work the land using high value external inputs, while largely ignoring the benefits of land that is underlying natural or human-induced ecological restoration and conservation (Mousseau, 2019). Moreover, restoration of soil quality and the cleaning up of contaminated soil is labour intensive and seldom beneficiary of direct governmental subventions. This obliges us to ask: Do profit maximizing entities have adequate incentives to involve in longterm soil conservation efforts while leasing land? To provide an answer we offer a brief introduction to soils, discuss the characteristics of lease agreements and then assess the ethical issues of such deals.

\section{Soil quality: a historically underestimated good}

While humans from early on noticed that some lands where much more suitable for agriculture than others, the importance of maintaining soil quality has been historically poorly understood (Fouke, 2011). There are multiple factors that have contributed to this misunderstanding. After analysing the wide influence of Aristotle on physiology, some historians of science have attributed androcentric reasoning leading to overvalue the importance of seeds, symbolizing the male contribution containing all hereditary material, and to undervalue the role of good soils as the female counterpart, downgrading the function of soils to a simple (and interchangeable) nutrient provider (cf. The Biology and Gender Study Group, 1988). For instance, early studies on soil depletion, such as Justus von Liebig's identification of three basic chemicals (nitrogen, phosphorus and potassium) that needed to be replaced to maintain soil fertility are, as is now well known, oversimplified (Pollan, 2008). Only now, we are beginning to learn about the complexity of factors that affect soil quality and the diversity of ecological services soil organisms offer, which range from carbon capture, provision of clean air, improvement of vitamin and mineral content of crops, nitrogen fixation, increasing resilience to biotic and abiotic factors, and reducing soil pollutants (El Mujtar et al., 2019). Hence, the maintenance and improvement of essential soil functions (nutrient cycling, water regulation, biodiversity, and physical stability and support) has been generally neglected.

The historic failure to properly recognize the complexity of parameters influencing soil functions and services is not ethically neutral. It came with an overestimation of human agency, concentrating on the ability to shape land through European management methods, specially soil tiling with the plough, while misrecognizing the value of indigenous land stewardship and the role of nature (Plumwood, 2006). This has facilitated an image of land managed by indigenous communities as underused and unproductive, as something that needs to be modernized and put into good use with the help of foreign innovation. This conviction prevails despite the increased evidence on smallholders producing more food in proportion to the land they work, while providing valuable ecosystem services and conserving biodiversity (Ricciardi et al., 2018). We are slowly seeing a shift in mindset, while early work on sustainability concentrated on maintaining harvests yields, scientists, farmers and activists are increasingly recognizing the importance of maintaining soil ecosystems for future food security and the conservation of other living organisms (Puig de la Bellacasa, 2015). 


\section{Lease agreements and obligations}

As the reader has most likely witnessed, returning and receiving leased or borrowed objects is a tedious task, since disputes are likely to arise on the state of the object before and after the lease, on the eventual costs of repairs or on compensation for damages. It has become common practice to sign contractual agreements with detailed description of the object before the lease to reduce uncertainty. In the case of some of the more indispensable objects covered by social rights commitments, lawmakers have decided to interfere, and limit freedom of contract. We can see this in contracts among people with unequal bargaining power, such as with rental agreements for housing (Radin, 1986), where many countries have strict regulations on which costs the tenants have to bear and which they do not, on what types of damages they are responsible for and for which they are not, and on when they have to vacate the building. To avoid uncertainty and abuses, the object's condition and value needs to be assessed in an accurate and cost-effective way at the beginning and end of the lease.

It is exactly in this regard where land leases, particularly in large-scale over longer periods, cannot provide certainty and are remarkably different from other tenancies. Renters, in contrast to owners, generally do not possess a right to significantly alter, consume or destroy the good (Wells, 2019). Yet using land involves alterations and in conventional agriculture, also the consumption of parts of the rented object (i.e. soil quality) and in cases of careless exploitation also its destruction (i.e. soil erosion). Land undergoes major transformations when it is leased, and it is difficult to agree on what can count as normal or acceptable form of land management, as we find such strong disagreements on what counts as good agricultural practice. When assessing soil quality, we can cost-effectively only gather information based on random samples concerning basic elements, such as soil nutrient content and acidity, which leaves out other agroecologically highly important variables such as diversity and composition of soil micro- and macro-fauna, soil physical structures, soil water retention capacity and infiltration, as well as management and soil conservation practices (e.g. mulching, contour planting, compost addition). Here we should also consider that land is leased at extremely low prices, sometimes even at $\$ 1$ a hectare a year in parts of Africa (Schiffman, 2013) - a price that cannot compensate adequate soil monitoring. Moreover, it is difficult or impossible to set a monetary value on eroded soil, due to the lengthy time periods needed to restore soils, if possible at all (Fouke, 2011). Soil fertility is a slowly renewable good on which food security is strongly dependent upon, and while the resource can be depleted relatively quickly (e.g. when no soil conservation measures are practiced), it takes a very long time to be restored - increasing soil organic matter by $1 \%$ can take decades. Soil quality on agricultural lands are largely governed by organic matter additions. In order to promote soil organic matter build-up, great amounts of organic matter need to be applied and maintained on the land. If soils are unprotected or poorly managed, and moreover exposed to heavy rainfall, then soil dynamics shift from "build-up" to erosion and the loss of precious nutrients, eventually leading to the depletion of soil functions (or soil productive capacity). Reversing this phenomenon is possible by heavy investments. In the case of soil erosion, the damages can be irreparable or involve prohibitive costs. To give an idea about these costs, the massive deforestations during the Roman Empire in the Eastern Mediterranean led to the erosion of highly valuable agricultural land, which has not been recovered despite the passing of so many centuries (Mazoyer and Roudart, 2006).

There are also strong incentives to ignore good soil stewardship. Particularly towards the end of the lease tenants have little incentive to conserve soils, especially when costs are high and certainty about the possibility of future use low. We can already observe significant losses in soil nutrient content in studies of short-term leases in Finland, despite the wider availability of resources to monitor soils (Myyrä et al., 2007). Soil conservation involves costs and the 
advantages of investing in soil restoration may take some years to result in improved or stabilized yields. In Burkina Faso, for example, where lands are relatively poor, adding $12 \mathrm{t}$ $\mathrm{ha}^{-1}$ of woody biomass will allow the maintenance of soil carbon in time, yet these amounts are four times as high as the available biomass in the surrounding landscapes $\left(3 \mathrm{t} \mathrm{ha}^{-1}\right)$, which are not enough to counter soil carbon losses (Félix et al., 2018). Through the integration of woody shrub perennials and other smart-uses of biodiversity (e.g. termites), soil quality could be maintained to ensure stable crop productivity and feed local populations. Agricultural extension programs need to improve the diffusion of such techniques.

There have been some attempts to oblige tenants to comply with certain usages. Yet to make sure that tenants do really comply with these regulations or recommendations it is crucial that the landowner is able to sanction non-complying tenants. To do so the local government protecting such resources needs to have sufficient power over the tenant, something that is often missing when land is leased by international corporations and foreign governments who can retaliate more strongly. Here we need to draw attention to the context of extreme inequality within such negotiations. When settling disputes between two private parties, where evidence about damages is difficult to obtain, it is much more likely that the stronger party wins. Since land on a massive scale is usually acquired from financially poorer countries, it is likely that they will not succeed in receiving any substantial compensation. In this case the local government can only rely on (corporate) social responsibility and international public outcry to maintain soil quality, which is also insufficient if the different parties have inadequate knowledge on the baseline conditions of soils and their importance. In addition, the local government has to have an interest in good stewardship. In terms of rights and principles of sovereignty, the government in power, irrespectively of its legitimacy, is usually seen at an international level as authorized to negotiate over national resources. This has been severely criticized for its effect on contributing to structural global injustice as it allows corrupt governments to remain in power and drain national resources for their personal interests (Toft, 2013). Recognizing corrupt governments as fully entitled to negotiate over national resources has also negative effects for both leasing and receiving property after lease agreements expire. Governments are responsible on view of the interests of present and future citizens to act as good stewards of the land they exert sovereignty on, which is not effortless, as it requires awareness of the importance of soils, involves monitoring, policing and demanding compensation for damages, even when doing so comes at odds with other present-day political interests. Unfortunately, ignorance about the importance of soils and their vulnerability is widespread (Puig de la Bellacasa, 2015).

\section{Fairness and the distribution of burdens of soil restoration}

Land leases can mean much more then temporary unavailability of a resource for the local population. It may involve the destruction of a very slowly replaceable asset (soil quality) and in large-scale leases even the loss of biodiversity, including the loss of traditional landraces and their associated traditional knowledge. Therefore, it is important to ask ourselves: who is currently doing the work involved in soil restoration? Are farmers being assisted in such efforts? And, are they being recognized for the provision of valuable ecosystem services, such as carbon capturing from the atmosphere?

Here it is important to note that in particular smallholders are pushed towards marginal lands, often after they have been evicted of the lands they have traditionally occupied to make room for large infrastructural projects, the creations of national parks, and the occupation of lands after their acquisition by national and foreign corporations (De Schutter, 2011). These smallholders end up with the difficult task of recovering the soils to be able to produce food. The amount of effort, resources and time such efforts take varies strongly depending of the soil type, baseline conditions, climate, vegetation (both natural and planted), animals and 
insects available. In China's Loess Plateau, soil conservation measures such as terracing, afforestation, and construction of sediment-trapping dams were extensively implemented since the 1950s through government programmes, reversing degraded agroecosystems into land cover changes and consequently the restoration of soil functions and the recuperation of natural water flows (Zhang et al., 2008). A large-scale government effort facilitated this process, without which the local farming families would be still depleting landscape resources and suffering from severe consequences of drought, preventing mass-migration. There is a certain arbitrariness on who ends up receiving support for soil conservation. Farmers from many other regions of the world have not benefitted from such programs and had to rely on their own effort. As governmental support varies, we need to recall that the failure to assist farmers' efforts is particularly unfair when we acknowledge that the public benefits - in terms of ecosystem services - outweigh the private benefits - in terms of increased yields (Franco, 2007).

Unsustainable exploitation of soils can have an effect that will be perceptible over many generations, making it an issue for intergenerational justice, considering that the present is jeopardizing access to a resource people in the future will have a fundamental interest in and inflicts costs on future generations without offering something of comparable value in return. These types of deals become even less acceptable from an ethical perspective if we consider that they are not a necessity and that alternatives exist. Land could be distributed in smaller plots giving people urgently needed means to grow their food and so be entitled to what they produce, reducing hunger (Rosset, 2009). Smallholders are doing a better job in soil conservation, have higher food yields, capture carbon and are conserving landraces. This calls for agrarian reforms. In addition, there is increasing evidence on the advantages of exploring and rediscovering alternative land management arrangements, such as the commons. These arrangements provide much more than an opportunity to grow food using sustainable production methods, they often also serve communities as a place of gathering, of exchanging knowledge, and of recovering and practicing traditional methods, providing room and opportunities to share meals and to build networks capable of solving other social challenges (Maughan and Ferrando, 2018).

\section{Conclusion}

Soil quality is a far too important resource to leave at the fate of corporate social responsibility or the goodwill of foreign governments alone. In practice, local governments can seldom exert sufficient pressure on tenants to secure adequate soil conservation. While this is also partially true for national corporations and large-scale land owners, local governments still retain some options to enforce conservation measures and penalize noncompliance. Most importantly, they can do so without fearing substantial international retaliation or trade disputes. Moreover, we nowadays know about the historical Eurocentric and androcentric biases that have led to the widespread ignorance about the true value of soils. This misrecognition deserves restoration. It has led to a situation where host countries are counting on the goodwill of contracting parties to ensure the conservation of a vital resource (i.e. soil quality) needed to secure the human right to adequate food. We need to give up the idea that long-term land leases affect only people and the environment in the near future.

Acknowledgement: CT's contribution was funded by a postdoctoral fellowship FONDECYT/ CONICYT No. 3170068.

\section{References}


De Schutter, O., 2011. How Not to Think of Land-Grabbing: Three Critiques of Large-Scale Investments in Farmland. Journal of Peasant Studies 38: 249-279.

El Mujtar, V., Muñoz, N., Mc Cormick, B.P., Pulleman, M. and Tittonell, P., 2019. Role and management of soil biodiversity for food security and nutrition; where do we stand? Global Food Security 20: 132-144.

Félix, G.F., Clermont - Dauphin, C., Hien, E., Groot, J.C.J., Penche, A., Barthès, B.G., Manlay, R.J., Tittonell, P. and Cournac, L., 2018. Ramial wood amendments (piliostigma reticulatum) mitigate degradation of tropical soils but do not replenish nutrient exports. Land Degradation \& Development 29: 2694-2706. 10.1002/ldr.3033

Fouke, D.C., 2011. Humans and the Soil. Environmental Ethics 33: 147-161.

Franco, J.A., 2007. Ética intergeneracional en la conservación del suelo agrario. Revista de desarrollo rural y cooperativismo agrario 11: 9-18.

IPBES, 2018. Assessment Report on Land Degradation and Restoration, Secretariat of the Intergovernmental Science-Policy Platform on Biodiversity and Ecosystem Services, Bonn.

Maughan, C. and Ferrando, T., 2018. Land as a commons. In: J.L. Vivero-Pol, T. Ferrando, O. De Schutter and U. Mattei (Eds.), Routledge Handbook of Food as a Commons. Routledge, Oxon \& New York.

Mazoyer, M. and Roudart, L., 2006. A history of world agriculture: from the neolithic age to the current crisis. Monthy Review Press, New York.

Mousseau, F., 2019. The highest bidder takes it all. Oakland Institute, Oakland.

Myyrä, S., Pietola, K. and Yli-Halla, M., 2007. Exploring long-term land improvements under land tenure insecurity. Agricultural Systems 92: 63-75.

Ota, K., Murata, T., Ohkura, T. and Hamada, R., 2018. What Does "Soil Is Valuable" Mean? Institutional Design and Ethics for Sustainable Use of Soil Resources. In: P.B. Thompson and K.O. Thompson (Eds.), Agricultural Ethics in East Asian Perspective. Springer, Cham, pp. 197-211.

Plumwood, V., 2006. The concept of a cultural landscape: Nature, culture and agency in the land. Ethics and the Environment 11: 115-150.

Pollan, M., 2008. In defense of food: An eater's manifesto. Penguin, New York.

Puig de la Bellacasa, M., 2015. Making time for soil: Technoscientific futurity and the pace of care. Social Studies of Science 45: 691-716.

Radin, M.J., 1986. Residential rent control. Philosophy \& Public Affairs 15: 350-380.

Ricciardi, V., Ramankutty, N., Mehrabi, Z., Jarvis, L. and Chookolingo, B., 2018. How much of the world's food do smallholders produce? Global Food Security 17: 64-72.

Rosset, P., 2009. Fixing our global food system: Food sovereignty and redistributive land reform. Monthly Review 61: 114-128.

Schiffman, R., 2013. Hunger, food security, and the African land grab. Ethics \& International Affairs 27: 239-249.

The Biology and Gender Study Group, 1988. The importance of feminist critique for contemporary cell biology. Hypatia 3: 61-76.

Toft, K.H., 2013. Are land deals unethical? The ethics of large-scale land acquisitions in developing countries. Journal of Agricultural and Environmental Ethics 26: 11811198.

Wells, K., 2019. Renting Personal Goods. Social theory and practice 45: 127-148.

Zhang, X., Zhang, L., Zhao, J., Rustomji, P. and Hairsine, P., 2008. Responses of streamflow to changes in climate and land use/cover in the Loess Plateau, China. Water Resources Research 44. doi:10.1029/2007WR006711 